Administrative Issues Journal: Connecting Education, Practice, and Research, Winter 2016, Vol. 6, No. 2: 13-29. doi:10.5929/2016.6.2.1

\title{
Impact of a Student-scheduled Child Care Program on Parents' Educational Goals
}

\author{
Barbara Carter, D.Ed.M. \\ University of Central Oklahoma
}

\begin{abstract}
The purpose of this study is to examine what, if any, impact a Student-scheduled Child Care (SSCC) program had on the families of students completing their higher education goals at a college in the southwestern region of the United States. Student completion rate is a concern for most college and university administrators. Research conducted by the Gates foundation determined that over three quarters of former students surveyed felt that they would have graduated if the college or university had offered child care (Johnson, Ott, \& DuPont, 2011). This correlational and descriptive research study revealed what student families thought about the relationship between completing their educational goals and using the child care program at the college. The knowledge gained from this project could help to initiate a broader discussion among colleges and universities of how to most effectively retain student families by meeting their child care needs.
\end{abstract}

Key words: higher education, student retention, completion rate, high quality child care, student-scheduled child care, non-traditional students, student families

T

he Child Development Center and Lab School (CDCLS) of a college located in a metropolitan city in the southwestern part of the United States introduced student-scheduled child care to the campus community during the summer semester of 2008. The pilot program was created to help meet the child care needs of student parents by providing low cost, high quality child care as defined by state licensing (OKDHS, 2013) and national accreditation through the National Association for the Education of Young Children (NAEYC, 2012). In an interview, the president of this college indicated that the inspiration for the program came from conversations with students. He had simply asked the students what they would change if they were president of the college, and one of the predominate responses was reliable, affordable, high quality child care. The university president shared that a student once told him that they were one failed babysitter away from dropping out of college (P. Sechrist, interview, November 26, 2013). 
The program, now in its ninth year, is designed for children six weeks to eight years old. Student parents are defined as college students enrolled in credit earning classes who have custody of minor children. A number of the student parents in the program are single parents, parents with deployed spouses serving in the United States military and family members with custody of young children. Student parents enroll and reserve a spot for their child that corresponds with their entire class schedule. A pre-enrollment process provides the lab school with all the necessary information required by state licensing and national accreditation systems when caring for young children.

The lab school, which began on the main campus of the college and is currently located one mile north of the main campus on college property, serves both the college and greater community. Typically, a lab school is a functioning school with the dual purpose of educating children and mentoring pre-service teachers. With full time and Student-scheduled Child Care program children enrolled, the lab school can schedule degree-seeking students from area colleges and universities who are required to observe in classrooms of young children. The lab school in this study opens its doors to three area universities, three community colleges, the Department of Human Services, area child development centers, and professional development centers for early education. Students from the fields of early childhood education, elementary education, allied health, nursing, psychology and sociology conduct labs and/or have observation assignments at the lab school.

Student parents can enroll their children for the number of session times needed; this option allows families to pay for only the child care needed while they attend classes, lowering the general child care cost considerably. The following sessions are offered:

- Session One: 7:30 to 10:45 a.m.

- Session Two: 11:00 a.m. to 2:15 p.m.

- Session Three: 2:30 to 5:45 p.m.

- Session Four: 6:00 p.m. to close

For example, a student parent may have a Monday, Wednesday, Friday class from 8:00-9:00 a.m. Such parents would enroll their child for Session One, which extends from 7:30 a.m. to 10:45 a.m. for the three days throughout the eight or sixteen week semester. Any additional time remaining in a scheduled session is available to the student parent to use for study, research, cohort meetings, and appointments with staff and/or faculty.

As a lab school, having predetermined time frames with consistent enrollment also allows the CDCLS to schedule college students in various fields of study who are required to carry out observations of children/teachers and/or who conduct lab activities with the children under the close supervision of center instructional staff. As a child development center, this allows the CDCLS to plan meaningful, educational activities for all the children. Low transition and consistent care for young children promotes a secure environment and self-confidence in the children (Sytsma, Kelley, \& Wymer, 2001; Wildenger, 2008).

CARTER / doi:10.5929/2016.6.2.1 


\section{Review of Literature}

Although early childhood education and college graduation may be at the opposite ends of the academic spectrum, a closer connection than many realize might exist. A brief review of the literature will investigate college retention trends, explore the nature of the challenges non-traditional students face, and elicit an understanding of the role high quality child care plays in college students completing their educational goals.

\section{College Retention Trends}

Student retention is a concern on most college and university campuses in the United States. Colleges and universities spend millions of dollars each year to retain their student rosters (Wild \& Ebbers, 2002). President Barack Obama and his administrative leadership have voiced the concern of a nation regarding its declining educational system. In the same tradition as a number of former United States leaders, President Obama has expressed a belief that the key to the economic prosperity of a growing nation lies within the halls of education. With community colleges being the largest sector of higher education in the United States, President Obama has challenged these institutions, with their six million plus students, to increase the number of graduates by five million by the year 2020 (Obama, 2009).

Although some students may not fully realize the personal impact of dropping out of college (Johnson et al., 2011), most students would agree that there is some financial benefit to earning a college diploma. A recent research study showed that, over an average lifetime, the income of an employee with a college degree will have consistently doubled that of a wage earner who did not graduate from an intuition of higher education (Alarcon \& Edwards, 2013). Georgetown University on Education and the Workforce has projected that, by 2018, current and new businesses in the United States will need an estimated twenty-two million new college educated employees to sustain their workforces. This would indicate that sixty-three percent of the jobs in America would require a minimum of an Associate's degree. The researchers at Georgetown University believe that, at the current rate of college graduation, the United States will fall short of this goal by a conservative three million employees (Carnevale, Smith, \& Strohl, 2010). The current presidential administration is willing to commit an approximate twelve billion dollars to higher education reform, starting with community colleges (Obama, 2009).

Despite growth trends indicating college enrollment steadily increasing over the last several years, with nearly two and a half million expected to enroll by 2015 (Hovey, 2000), a significant number of these students will not graduate (Morrow \& Ackermann, 2012). Less than $60 \%$ of the students in the United States who begin a college career ever realize the dream of completing a degree (Erickson, 2012; U.S. Department of Education, 2006-2007). The current trend of declining retention is not limited to the community college campus. Consistent with earlier research, a number of universities awarding postgraduate degrees and boasting top research programs struggle to keep their students (Bound, Lovenheim, \& Turner, 2010). A survey of four-year programs reported a $22 \%$ retention drop between the freshman and sophomore year of college (ACT, 2011).

CARTER / doi:10.5929/2016.6.2.1 
Students appear to start off well as highly motivated students and then, somewhere along the first several months of their college careers, many withdraw from their programs or merely stop attending classes. Researchers have discovered that the most significant drop occurs in the last quarter of the freshman year (Alarcon \& Edwards, 2013). Sparkman, Maulding, and Roberts, in a recent study, have determined that young, single, white females who live in the dorm have the highest graduation rate (2012). Typically, students without circadian family responsibilities, who have support and resources sufficient enough to allow them to focus on academic endeavors and who have time to connect with their college campuses through various social, academic, professional and civic organizations will graduate. Research indicates that there may be a connection to gender, as drop rate seems to be higher among male students than among female students (Bound et al., 2010).

Traditionally a person's high school grade point average, and American College Testing (ACT) or Scholastic Aptitude Test (SAT) scores were key indicators of a $25 \%$ variance of success at the university level (Sparkman et al., 2012). Current research supports the theory that possessing adequate support, resources, and academic aptitude are considerable factors in retention. A reduction in available resources correlates with a declining retention (Alarcon \& Edwards, 2013; Bound et al., 2010; GoldrickRab \& Sorenson, 2010). Higher levels of emotional intelligence and a sense of social responsibility have also been associated with greater college completion rates (Sparkman et al., 2012). This influence aspect of social responsibility on retention echoes the research of Morrow and Ackermann's recent study, which revealed that regardless of a student's background or prior experience, if he or she had a sense of belonging, this helped sustain intentions to persist in scholastic rigor (2012).

\section{Nature of Non-traditional Students}

The vast majority of American college campuses are filled with nontraditional students, and research indicates that this enrollment trend is growing. Seventy-five percent of all university and college students in the United States are considered nontraditional students (Jones, 2011), and nontrads are the fastest growing population (Wyatt, 2011). Since the early 1800 's, nontraditional student enrollment has outnumbered that of traditional student enrollment (Villella \& Hu, 1991). A report published by the United States Department of Education projects that, by the year 2019, the number of nontraditional students will rise to $23 \%$ over the $9 \%$ growth rate predicted for traditional students (2011).

The face of the U.S. American college campus has changed dramatically over the past one hundred years. Early in the United States academic history, college campuses were reserved for young, single, white males who typically came from wealthy families or perhaps young scholars sent from their communities to study medicine and return as town physicians. Colleges and universities were almost exclusively resident campuses, with very few commuters. Over the last several decades, the concept of a nontraditional student has also changed in keeping with the growing face of diversity on college campuses. Classifications such as socioeconomic status, sex, and ethnicity no longer define nontraditional students (Ogren, 2003). The current nontraditional college student is not defined primarily by parameters beyond his or her control, but rather by life choices and circumstances.

CARTER / doi:10.5929/2016.6.2.1 
Nontraditional students bring to university and college campuses a vast array of life and work place experience coupled with complex challenges. While the definition is broad, typically nontraditional students are learners who are older than twenty-five, work full or part-time, are financially independent, and/or have family responsibilities (Villella \& Hu, 1991). Nontraditional students are more often than not considered low-income families and are typically first generation college students (Miller, 2012). Kenner and Wienerman classified the majority of nontraditional students into three major categories of life experience: those who have postponed education, those who have served in the nation's military, and those needing a career change (2011). Each category possesses unique challenges and costs.

Many nontraditional students are adults who may have begun families or entered the workforce before high school graduation and have recently completed the General Educational Development (GED) test (GED, 2009). Today, a large number of nontraditional students on campuses are returning veterans who served in the United States military, most in recent international combat. The economic recession in 2008 rendered many United States citizens without jobs (Margalit, 2011). With the need to find work, thousands of adults flooded college campuses in search of new marketable skills (Kenner \& Wienerman, 2011). Katopes asserted that experience, discipline, and dedication make these nontraditional students valuable students in the classroom (2009).

A delay in enrollment from high school to college presents a unique set of consequences that may make nontraditional students less likely than their traditional peers to graduate from two-year programs or transfer to four-year institutions (Horn \& Premo, 1995; Niu \& Tienda, 2013). Goldrick-Rab and Sorenson found that not knowing what to expect or how to navigate the college system may leave many nontraditional students unable to attain their educational goals (2010). Many leave simply because they are not academically or financially prepared to get an education.

Some struggles maybe common among all students; however, nontraditional students have the distinctive challenge of balancing family responsibilities and maintaining a sustainable income, all while taking on the rigors of the academic world (Stone \& O'Shea, 2013). Additional responsibilities preclude participation in extracurricular or service activities. Participation in events or organizations outside of class is a challenge to most nontraditional students. A national survey of student engagement revealed that nontraditional students are less likely to participate in community service than are their traditional counterparts. Forty-seven percent of nontraditional students as compared to $69 \%$ of traditional students engage in community participation or service. In regard to extracurricular activities, $69 \%$ of traditional undergraduates participate, whereas only $27 \%$ of nontraditional students are involved (2006).

Nontraditional students have their challenges; however, along with these challenges they bring a distinctive understanding of the world derived from their life experiences. Morris, Brooks, and May discovered that, unlike traditional students, older students tended to be proactive in confronting learning stress. Nontraditional students characteristically desired a greater understanding of a subject as compared to their younger counterparts, who were typically more concerned about earning a grade (Morris, Brooks, \& May, 2003). Nontraditional students, on average, participated more in class discussions and were more conscientious about their work product. In a national survey of student engagement, $80 \%$ of nontraditional students would ask questions in class compared to only $72 \%$ of 
traditional students. Nontraditional students were more likely to hand in several drafts or revisions of work, as opposed to traditional students. A quarter of the traditional students surveyed regularly attended class unprepared, whereas nearly $90 \%$ of nontraditional students would come to class ready with assignments and readings completed (National Survey of Student Engagement, 2006).

The demographic of nontraditional college students is in correlation with the changing workforce in the United States. There has been a significant increase of women in the workplace over the past three decades. In 1975, The U.S. Department of Labor, Women's Bureau, reported that 39\% of female workers had children under the age of six, and in 2011, the agency reported a $25 \%$ increase, with $64 \%$ of working women having children under the age of six years (2013).

The nontraditional student body consists of approximately $71 \%$ females, with nearly half of these being unmarried (Miller, 2012). Most women feel that they are or should be the primary caregiver of young children (Deutsch, Kokot, \& Binder, 2007). Not only is being the primary caregiver to their children important, research indicates that, for many, being a mother is more important to self-image than is being a college graduate (Devos, Diaz, Viera, \& Dunn, 2007). Although nontraditional student parents are grouped with all nontraditional students, they have significantly different demands as caregivers of dependent children (Austin, 2010; Van Rhijn, Quosai, \& Lero, 2011). It is important to support this evergrowing student population. The stress involved in being a parent and student along with the task of financially providing for a family can be overwhelming. A study conducted by Quimby and O'Brien found that when student parents, especially mothers, were supported socially and economically and demonstrated secure attachment, they had a healthier psychological profile (2006).

\section{High Quality Child Care}

College campuses are continually growing, most of which with nontraditional students. Many learners who have been in hiatus are returning to campus, bringing their families with them. According to studies conducted by the National Center for Educational Statistics, approximately 53\% of all independent undergraduate students have dependent children (2013), and a minimum of $70 \%$ of all children younger than six attend some form of child care outside of their own homes (US Department of Labor, Women's Bureau, 2000). The importance of the issue is that institutions of higher education might be failing to recognize the changing demographics of the twenty first century college student. Many student families need high quality child care assistance in order to complete their educational goals (Brooks, 2012). Research has shown that without education there is very little meaningful change in the lives of people, families, and ultimately communities. While many programs have been established to assist young adults in completing their educational goals, improvements are still necessary (Brock, 2010).

Research indicates that there are multiple benefits of higher education for the community and the individual; however, the positive impact on the family, especially young children, may be evident for generations (Sommer et al., 2012). Increasing access to higher education for parents and high quality child care for children is a win-win situation.

CARTER / doi:10.5929/2016.6.2.1 
High quality child care renders many benefits. Child care with purposeful instruction, intentional environment, and well-educated teachers creates a dynamic platform for childhood learning. A policy statement on quality early education and child care from birth to kindergarten supports the idea that consistency and quality child care (when it extends to the home) improves the child's health, development, and social growth (Quality Early Education and Child Care from Birth to Kindergarten, 2005). A child's early experiences whether in the home, the classroom or community are educational experiences (US Department of Labor, Women's Bureau, 2000). The National Research Council and Institute of Medicine, the Board on Children, Youth, and Families, and the Commission on Behavioral and Social Sciences and Education has determined that early brain development is strongly affected by a child's surroundings and early experiences (2000). Classroom environment affects children's development (Colburn, 2009; Sommer et al., 2012). High quality child care provides intentional and developmentally appropriate environments for children's educational experiences. High quality child care environments provide a sense of routine, which is important in a child's development because it gives the child a sense of security (Sytsma et al., 2001).

High quality child care provided by or partnered with college and university campuses may be a key to the retention dilemma for nontraditional students with young children. A number of top research universities such as Princeton, Cal-tech, and John's Hopkins University have realized the importance of child care for their teams of researchers, of whom a third have young children. These universities have responded to this need by providing child care centers on campus (Gewin, 2005). Campus child care not only provides a quality learning experience for young children, but also affords an educational opportunity for parents. The University of Arkansas found that having their child development center on campus opened doors to providing emotional support as well as parent education opportunities (Baldwin, Da Ros-Voseles, \& Swick, 2003). Western Michigan University published an article that outlined how they used funds awarded to them by the Child Care Access Means Parents in School (CCAMPIS) grant to focus on building relationships with parents and providing educational resources, which became key to retaining student parents at the university (Nelson, 2007).

High quality child care is an expensive endeavor. Campus child development centers cost an average of $\$ 1.5$ million dollars a year to operate. It is no wonder that so few campuses will take on this financial responsibility. Of the more than seventy research institutions in United States, only $10 \%$ offer campus child care (Gewin, 2005). If well-endowed research universities find it difficult to support a campus child care program, how much less the local community college campus. The investment in campus child care centers is considerable; however, the return rate for the investment in student families has the potential to be worth the cost, rendering a well-educated and skilled U.S. American workforce.

\section{Method}

The design of this action research project is considered a combination of a correlational study and descriptive research, in which researchers attempt to describe data and characteristics about the population, answering who, what, where, when and how (Slavin, 2012). A college in the southwestern region of the United States has made an attempt to meet the child care needs of student families while helping their college increase the retention rate of its students. The researchers found that there was a 
significant impact on the educational goals and retention rate of students who had children attending a campus child care program designed around their class schedules.

In the first element of the study, the researchers investigated the enrollment and graduation rate of student parents who had children enrolled in the SSCC program. Researchers sought to determine the number who have or are currently completing their educational goals. Educational goals, for this study, was defined as having graduated with a certificate, degree or being currently enrolled in the college (at the time of the study). Student parent information was collected from CDCLS enrollment records for the years between 2005 and 2013. This list was submitted to the graduation and enrollment records department of the college for the same years in order to determine if the families on the CDCLS enrollment list had or were in the process of obtaining their educational goals.

In the second element of the study, the researchers invited participants to reflect on their college experience as student parents and respond to a 10-question survey. For this study, only the first five questions of the survey will be addressed. While participants were given a choice to respond to the survey electronically or by hardcopy format, all participants chose to respond by electronic means. A web-based, third party survey company was used to create the survey and collect the data. System protocols were set in place to guard the anonymity of the participants and their responses. The survey made use of objective, subjective, and ranking responses.

A third element of the study included member review. The research team, as well as the appropriate research and statistics departments of the college, conducted a data review. A member of the research team may retain a negligible bias as to the effectiveness of the program as they serve as the enrollment administrator for the student-scheduled child care program at the college.

Limitations to this study included a relatively small sample of participants: forty of 395 possible respondents. The first element of the study only accounted for graduates and those who were currently enrolled in the college. A second limitation was that it did not take into account student parents whose educational goals included transferring to a four-year university.

\section{Participants}

Participants in this study were college students in attendance at a metropolitan community college in the southwest region of the United States who had their children enrolled in the child development center and lab school of the college. The college offers certificates, associates of arts/science, and associates of applied science degrees. The general demographics of the college reflect a diverse population. The community college is the fourth largest institution for higher education in its state (and is considered to be more diverse than the surrounding five counties from which $90 \%$ of the student body hails. The Non-Hispanic White students make up $61.8 \%$ of students enrolled; $10.6 \%$ African American, 10.3\% Hispanic, 3.0\% Asian, and 3.7\% Native American, and $6.1 \%$ consider themselves to be a combination of two or more ethnic groups. The college has approximately 450 international students in attendance (OCCC Office of Institutional Effectiveness, 2012). Participants were randomly selected from 
the enrollment pool of student parents who had their children (ages six weeks to eight years old) at the college child development center and lab school while they attended classes.

\section{Results}

The first element of the action research project was an extensive search conducted by researchers to determine how many CDCLS student parents had graduated or were in the process of completing certificates or degrees at the college. Information was collected from CDCLS enrollment records for the years 2005-2013. This list was submitted to the graduation and enrollment records department of the college for the same years in order to determine if the families on the CDCLS enrollment list had or were in the process of obtaining their educational goals.

\section{Enrollment and Completion Rates}

A review of the enrollment records for the CDCLS revealed there was an enrollment of 473 children, with parents attending the college, between the fall semesters of 2005 and 2013. Children can be enrolled in the program in one of two categories; full time (7:00 a.m. to 5:45 p.m., Monday-Friday, closed only when the college business offices are closed) or student-scheduled, based on the student parent's class schedule. Between the fall semesters of 2005 and 2013, 86 children were enrolled as fulltime children of student parents, and 353 were enrolled in the Student-scheduled Child Care program. Families beginning in the Student-scheduled Child Care program that transitioned to the full time program numbered 34 . During the years being analyzed, eight families had both parents attending college at the same time, and 465 participants had only one parent attending college classes.

The number of student parents enrolled in a degree or certificate program at the college who had children enrolled in the college's lab school numbered 395. While many students (families) needed the SSCC program for only one semester a considerable number of families used the services for multiple semesters (see Table 1). Student parents who completed or who were in the process of completing their educational goals, as defined by having graduated or who were currently enrolled, was 253 . The percentage of student parents who completed or who were in the process of completing their educational goals was $64.05 \%$.

\section{Student Parent Survey}

The second element of the action research project was a 10-question parent survey. Parents were invited to participate and given a brief explanation of the research project. Upon agreeing to participate, parents received an electronic message with a link to an Internet-based survey company, where they were directed to the online survey. Protocol was in place to ensure the anonymity of the participants. Forty-seven student parents agreed to participate in the survey, with 40 completing it during a nine week period of time in which surveys were collected by the researchers. There was an $85.10 \%$ return rate of the survey, which rendered both qualitative and quantitative data. 
Table 1

Student-scheduled Child Care Enrollment

Number of Semesters

Number of Children

One semester participation in program

473

Two semesters participation in program

248

Three semesters participation in program

156

Four semesters participation in program

89

Five semesters participation in program

Six semesters participation in program

Seven semesters participation in program

Eight semesters participation in program

9

Nine semesters participation in program

Ten semesters participation in program

Note. Number of children enrolled in the CDCLS with student parents: 395 ; student parents obtaining or completed educational goals: 253; percent of student parents obtaining or completing educational goals: $64.05 \%$.

The first question asked of participants was, "How long did your child(ren) attend the CDCLS while you were a student at [the college]?" Thirty-nine participants responded to this question, with $25.64 \%$ indicating that they participated in the program for one semester (either for an eight or sixteen week semester during the summer (June and July), the fall (August through December), or the spring (January through May). Participants answering "one semester" may have attended for only one semester or may have been in their first semester of the program at the time the survey was taken. Those who had participated in the program for two to three semesters made up $35.90 \%$ of the participants who responded to the survey. Those who were in the program for four to five semesters constituted $20.51 \%$, $15.38 \%$ of the respondents had attended the program for six to seven semesters, and those who have been involved in the program for eight or more semesters made up $2.56 \%$ of those surveyed.

The second question addressed the issue of availability of sessions amenable to student parents' schedules: "When enrolling your child(ren) in the Student-scheduled Child Care program, did you ever need to change your class schedule because there was not an available spot at the CDCLS for your child(ren)?" Seventy-four percent of the participants answered, "No, there was always an opening for my child(ren) when I needed them for class." Twenty-six percent of the student parents answering the question chose, "Yes, I had to change my schedule at least once to accommodate for child care." Thirtynine of the 40 respondents answered question two, with one participant choosing not to answer.

CARTER / doi:10.5929/2016.6.2.1

Page 22 
The third question attempted to measure student parents' perceived relationship between having low cost, high quality child care to meet their class schedules and being able to complete their educational goals (see Table 2). The response options ranged from "Not important. It was not a major factor - I had other options" to "Very Important. Without the child care program I would not have been able to go to class." An overwhelming majority of student parents indicated that having the child care option was very important to the completion of their educational goals. Without the program they would not have been able to attend classes.

Table 2

Question Three of the Student Parent Survey

Answer Options

Responses

Very important. Without the child care program I would not have been able to go to class. $89.74 \%(35)$

Important. It would have been difficult to attend classes without the child care program. $\quad 10.26 \%(4)$

Somewhat important. I could have attended classes without it. $\quad 0 \%$

Not important. It was not a major factor - I had other options. $\quad 0 \%$

Total

$39 *$

*1 answer skipped

The intent of the fourth question was to determine student parents' decisions to attend the college in relationship to the availability of child care on campus (see Table 3). Thirty-nine participants responded to the question. The question asked parents to what degree they agreed with the statement, "My decision to attend [the college] was, in part, because of the Student-scheduled Child care program." Two (5.13\%) of the participants strongly disagreed with the statement. One (2.56\%) disagreed; seven (17.95\%) neither agreed nor disagreed. Twelve participants $(30.77 \%)$ agreed with the statement, while the greatest percentage of student parents, $43.59 \%$ (17) strongly agreed.

Question five of the student parent survey addressed how these nontraditional college students paid for child care: "How did you pay for child care while at [the college]? (Mark all that apply.)" (see Table 4). It is important to note that participants had the option to choose more than one response as applied to their situation. For example, a student parent may have paid out of pocket while they waited to see if there would be any money left over from their financial aid distribution. A number of families qualified for Department of Human Services (DHS) assistance with child care. However, they may also have had monthly co-pay; therefore, it is possible that they responded that they used DHS assistance and paid out of pocket. 
Table 3

Question Four of the Student Parent Survey

\begin{tabular}{lc}
\hline Answer Options & Responses \\
\hline Strongly agree & $43.59 \%(17)$ \\
Agree & $30.77 \%(12)$ \\
Neither agree nor disagree & $17.95 \%(7)$ \\
Disagree & $2.56 \%(1)$ \\
Strongly disagree & $5.13 \%(2)$ \\
\hline Total & $39 *$ \\
\hline$* 1$ answer skipped & \\
Table 4 & Responses \\
Question Five of the Student Parent Survey & $52.50 \%(21)$ \\
\hline Answer Options & $2.50 \%(1)$ \\
\hline Out of pocket (paid for it by myself) & $30 \%(12)$ \\
Family member or friend paid for it & $2.50 \%(1)$ \\
Used leftover financial aid money (Pell grant) & $55.00 \%(22)$ \\
DHS assistance & $0 \%(0)$ \\
Special interest group Scholarship & $2.50 \%(1)$ \\
\hline Military child care assistance program & \\
\hline Total & \\
\hline
\end{tabular}

Twenty-one $(51.50 \%)$ of student parents indicated that they paid for child care out of pocket. One $(2.50 \%)$ of the respondents said that a family member or friend paid for their child care. Twelve families (30\%) answered that they used leftover financial aid monies to help pay for child care. The majority of the respondents indicated that they were able to pay for child care because of DHS assistance (22 families or $55.00 \%)$. No one chose the option of a special interest group scholarship. One individual 2.50\%) used the United States military child care assistance program and one indicated that they received a scholarship for the CDCLS (CCAMPIS grant) to pay for child care. 


\section{Discussion}

Results from the survey support the general premise that a student-scheduled child care program has a positive impact on student parents completing their educational goals. The first phase of the research project, which determined the graduation rate of those who had their children enrolled at the CDCLS, showed that over $64 \%$ of those student parents either completed or were in the process of completing their educational goals. The second phase of the project, the survey of student parents about their educational experience in relationship to the student-scheduled child care program, indicated that having high quality, low cost child care was a major factor in student parents' ability to complete their educational goals.

\section{Implications}

The results of the survey rendered a number of implications. Student parents indicated that the SSCC program enabled them to attend classes, with $74.36 \%$ of them returning to the center for more than one semester of child care while they continued or completed their educational goals. The flexibility of the SSCC scheduling seemed to indicate that more student parents were enrolling or maintaining enrollment in their academic programs. Just over $74 \%$ of the student parents were able to keep their original class schedule without needing to change due to child care needs. Perhaps one of the more significant implications of the study was that nearly $90 \%$ of those surveyed indicated that having the SSCC program available to them was very important, with nearly three-fourths indicating that having high quality, low cost child care available through the SSCC program was in part their reason for choosing this particular college.

\section{Conclusion}

This study supports the idea that a student-scheduled child care program positively impacts student parents, assisting them in completing their educational goals. With changing collegiate demographics, more students are in need of high quality child care. Student families need child care with a unique scheduling component that enables them to attend classes. Campus child care centers also have the potential to offer much in the way of living labs for professionals in training, and campus child care centers are a natural connection to the greater community. Perhaps the greatest benefit of a campus child care center is to the student who would not otherwise be able to accomplish his or her educational goals without a high quality child care option. It would benefit higher education administrators to consider the needs of student families when planning retention programs. The achievement of one parent graduate positively impacts the life of a family for generations to come.

References

ACT. (2011). 2011 Retention/completion summary tables. Retrieved from http://www.act.org Lnewsroom/data/2011/trends.html

CARTER / doi:10.5929/2016.6.2.1 
ACT. (2010). 2010 Retention/completion summary tables. Retrieved from http://www.act .org/research/policymakers/pdf/10retain trends.pdf

Alarcon, G., \& Edwards, J. (2013). Ability and motivation: Assessing individual factors that contribute to university retention. Journal of Educational Psychology, 105(1), 129-137.

Austin, C. (2010). Undergraduate working women's reflections on their progress in the last decade: The impact of work and study on female university students in Guyana. The International Journal of Learning, 17(4), 145-164.

Baldwin, V., DaRos-Voseles, D. \& Swick, K. (2003). Creating a caring community: The University of Arkansas nursery school experience. Early Childhood Education Journal, 30(3), 157-162.

Bound, J., Lovenheim, M., \& Turner, S. (July 2010). Why have college completion rates declined? An analysis of changing student preparation and collegiate resources. American Economic Journal: Applied Economics, 2, 129-157.

Brock, T. (2010). Young adults and higher education: Barriers and breakthroughs to success. Future of Children, 20(1), 109-132.

Brooks, R. (2012). Negotiating time and space for study: Student-parents and familial relationships. Sociology, 47(3), 443-459.

Carnevale, A., Smith, N., \& Strohl, J. (2010). Help wanted: Projections of jobs and education requirements through 2018. Georgetown University Center on Education and the Workforce, 12170.

Colburn, A. (2009). Brain based education. Science Teacher, 10-11.

Deutsch, F., Kokot, A., \& Binder, K. (2007). College women's plans for different types of egalitarian marriages. Journal of Marriage and Family, 69, 916-929.

Devos, T., Diaz, P., Viera, E., \& Dunn, R. (2007). College education and motherhood as components of self-concept: Discrepancies between implicit and explicit assessments. Self and Identity, 6, 256277.

Erickson, J. (2012). The condition of college \& career readiness 2013: First-generation students. ACT Council for Opportunity in Education, 2-20.

GED classes being deluged as unemployed seek new skills. (2009). Community College Week, 21(15), 3-4.

Gewin, V. (2005). Small steps toward campus child care. Nature, 437(15), 446-448.

Goldrick-Rab, S., \& Sorenson, K. (2010). Unmarried parents in college. The Future of Children: PrincetonBrookings, 20(2), 179-203.

Horn, L., \& Premo, M. (1995). Profile of undergraduates in U.S. post-secondary education institutions: 1992-93, with an essay on undergraduates at risk (NCES 96-237). Washington, DC: National Center for Educational Statistics.

CARTER / doi:10.5929/2016.6.2.1 
Johnson, J., Rochkind, A. Ott, \& DuPont, S. (2011). With his/her whole lives ahead of them: Myths and realities about why so many students fail to finish college. Public Agenda. The Bill and Melinda Gates Foundation, 20.

Jones, B. (Ed.) (2011). Degrees of difficulty: Take America to college. USA Today, Retrieved from http://usatoday30.usatoday.com/news/education/degrees-of-difficulty.htm

Katopes, P. (2009). Veterans returning to college aren't victims, they're assets. Community College Week, 21(15), 4-5.

Kenner, C., \& Weinerman, J. (2011). Adult learning theory: Applications to non-traditional college students. Journal of College Reading and Learning, 41(2), 87-96.

Margalit, Y. (2011). Costly jobs: Trade-related layoffs, government compensation, and voting in U.S. elections. American Political Science Review, 105(1), 166-188.

Miller, K. (2012). Child care: A critical campus resource for students with children. On Campus with Women, 40(3), 1.

Morris, E., Brooks, P., \& May, J. (2003). The relationship between achievement goal orientation and coping style: Traditional vs. nontraditional. College Student Journal, 37(1), 3.

Morrow, J., \& Ackermann, M. (2012). Intention to persist and retention of first-year students: The importance of motivation and sense of belonging. College Student Journal, 46(3), 483-491.

National Research Council and Institute of Medicine, Board on Children, Youth, and Families, Commission on Behavioral and Social Sciences and Education. (2000). In Shonkoff, J. P. \& Phillips D. A. (Eds.), From Neurons to Neighborhoods: The Science of Early Childhood Development. Washington, DC: National Academies Press.

National Survey of Student Engagement. (2006). Engaged learning: Fostering success for all students. Retrieved from http://www.nsse.jub.edu/

Nelson, R. (2007). A model for developing a parent resource center on campus. Journal of Early Childhood Teacher Education, 28, 1090-1027.

Niu, S., \& Tienda, M. (2013). Delayed enrollment and college plans: Is there a postponement penalty? The Journal of Higher Education, 84(1), 2-25.

Obama, B. (2009). Excerpts of the President's remarks in Warren Michigan and fact sheet on the American Graduation Initiative. Retrieved from http://www.whitehouse.gov/the press office/

Oklahoma City Community College Office of Institutional Effectiveness. (2012). Monitoring report on achieving the college's ENDs: Student access, May 21, 2012. Oklahoma City, OK: Oklahoma City Community College.

Ogren, C. A. (2003). Rethinking the "nontraditional" student from a historical perspective. Journal of Higher Education, 74, 640-664. 
Policy statement. Quality early education and child care from birth to kindergarten. (2005). American Academy of Pediatrics, 115(1), 187-191.

Quality Early Education and Child Care From Birth to Kindergarten. (2005). Pediatrics, 115(1), 187-191. doi:10.1542/peds.2004-2213Quimby, J., \& O'Brien, K. (2006). Predictors of well-being among nontraditional female students with children. Journal of Counseling \& Development, 84, 451460.

Slavin, R. (2012). Educational psychology: Theory and practice $\left(10^{\text {th }}\right.$ ed.). Upper Saddle River, NJ: Pearson Education Inc.

Sohmer-Tai, E. (2005). Women's work: Integrating women's studies into a community college curriculum. National Women's Studies Association Journal, 17(2), 184-191.

Sommer, T., Chase-Landsdale, P., Brooks-Gunn, J., Gardner, M., Rauner, D., \& Freel, K. (2012). Early childhood education centers and mothers' postsecondary attainment: A new conceptual framework for dual-generation education intervention. Teachers College Record, 114(100305), 1-40.

Sparkman, L. A., Maulding, W. S., \& Roberts, J. G. (2012). Non-cognitive predictors of student success in college. College Student Journal, 46(3), 642-652.

Stone, C., \& O'Shea, S. (2013). Time, money, leisure and guilt: The gendered challenges of higher education for mature-age students. Australian Journal of Adult Learning, 53(1), 90-110.

Sytsma, S., Kelley, M., \& Wymer, J. (2001). Development and initial validation of the child outlines inventory. Journal of Psychopathology and Behavioral Assessment, 23, 241-251.

U.S. Department of Education, National Center for Education Statistics. (2013). Graduation Rate File (IPEDS 2006-2007). Washington, DC: National Center for Education Statistics.

U.S. Department of Education, National Center for Education Statistics. (2011). Digest of Education Statistics, 2010 (NCES 2011-015), Table 235. Washington, DC: National Center for Education Statistics.

U.S. Department of Labor, Women's Bureau. (2000). 20 Facts on Women Workers. Washington, DC: US Department of Labor (1037) 43-45.

U.S. Department of Labor, Women's Bureau. (2013). Women in the labor force: A data book. Washington DC: U.S. Department of Labor (1040), 20-22.

Van Rhijn, T. M., Quosai, T., \& Lero, D. S. (2011). A Profile of undergraduate student parents in Canada. Canadian Journal of Higher Education, 41(3), 59-80.

Villella, E., \& Hu, M. (1991). A factor analysis of variables affecting the retention decision of nontraditional college students. National Association of Student Personnel Administrators Journal, 28(4), 334-341.

Wild, L., \& Ebbers, L. (2002). Rethinking student retention in community colleges. Community College Journal of Research and Practice, 26, 503-519. 
Wildenger, L., McIntyre, L., Fiese, B., \& Eckert, T. (2008). Children's daily routines during kindergarten transition. Early Childhood Education Journal, 36(1), 69-74. doi:10.1007/s10643-008-0255-2.

Wyatt, L. (2011). Nontraditional student engagement: Increasing adult student success and retention. The Journal of Continuing Higher Education, 59(1), 10-20.

\section{About the Author}

Dr. Barbara Carter (Bcarter23@uco.edu) is an Assistant Professor of Curriculum \& Instruction, Early Childhood Education, at the University of Central Oklahoma. Prior to becoming an Assistant Professor of Early Childhood Education in the Department of Curriculum and Instruction at the University of Central Oklahoma, Barbara J. Carter was the Assistant Director of the Child Development Center \& Lab School at Oklahoma City Community College. Before returning to her home state of Oklahoma, Dr. Carter was an adjunct professor at East Texas Baptist University and served internationally in the capacity of teacher, school administrator and educational consultant. Interest areas include religious education, leadership, early childhood education, cross-cultural studies, and multicultural education. 